\title{
Detection of plant viruses by molecular hybridization using non-radioactive probes ${ }^{1}$
}

\author{
by J. KUMMERT, D. COLINET and P. LEPOIVRE
}

Laboratoire de Pathologie Végétale, Faculté des Sciences Agronomiques, 13 av. Maréchal Juin, 5030 Gembloux (Belgium)

In the context of the phytosanitary legislation governing the trade of plants, accurate highly sensitive and rapid techniques of virus detection need to be developed. Such objectives can be achieved by molecular hybridization and PCR. Specific nucleic acid sequences of RNA viruses can be directly recognized by hybridization in the presence of labelled complementary DNA (cDNA) probes, synthesized either from purified viral RNA, from ds-RNA from infected plants, or from total RNA preparations from infected plants by RT-PCR. After characterization and selection, specific cDNA are cloned in bacteria by means of recombinant plasmids, allowing continuous availability of identical and homologous probes. Techniques of non-radioactive labelling, which can reach similar levels of sensitivity and specificity to the previous exclusive use of radioactivity, are used. Specific probes are generally hybridized to viral nucleic acid sequences from plant samples immobilized on solid support (dot-blot hybridization). Several examples for different viruses and host plants are presented, demonstrating the possibilities of the use of molecular hybridization for diagnosis of virus infection in plants.

\section{Introduction}

In crop production, the role of the phytopathologist is mainly to ensure that the plant material used is free from damaging diseases. This role is of increasing importance as the scale of movement of plant material within and between countries increases, and more defined official standards for certification of plant material are required. This is particularly true for vegetatively propagated planting material. In the member states of the European Union, phytosanitary certification of vegetatively propagated crops may soon be obligatory for several crops. The number of tests will thus increase accordingly, demanding simple, rapid and accurate routine tests.

Although the classical bioassay techniques will keep their importance for some time, particularly when very low concentrations of pathogens are to be' monitored (e.g. control of in vitro-regenerated material, some epidemiological or forecasting works), some new techniques in biology allow the pathologist to detect and identify the pathogens with more rapidity and good accuracy and sensitivity. Two main approaches for the detection of pathogens, and particularly of viruses for which isolation and multiplication of the pathogenic agent is not possible, are the use of immunological (ELISA) and nucleic acid hybridization and PCR technologies.

Besides detection, the new techniques have many possible applications in more fundamental or basic research work, such as taxonomy, study of variability of pathogens, etc. Due to their higher sensitivity, the new techniques may, however, bring about new problems concerning, for example, the sampling procedures and preparations.

${ }^{1}$ Paper presented at the EPPO Conference on New Methods of Diagnosis in Plant Protection, Wageningen (NL), 1994-01-25/28.

(C) 1995 OEPP/EPPO 
Molecular hybridization techniques for routine testing of viruses (and viroids) have shown a rapid increase in recent years, at least at the level of research laboratories. These techniques are based on the process of DNA strand separation and re-annealing, which can be used to hybridize single-stranded DNA or RNA molecules to a specific complementary sequence (the probe). They involve the use of labelled complementary DNA (or RNA) prepared from specific sequences of viral (viroid) nucleic acid. When incubated with plant extracts, in appropriate conditions, these probes will form detectable hybrids if the targeted viral sequence is present. The degree of specificity of detection is determined by the degree of sequence complementarity between the labelled probe and the target nucleic acid, but generally the test conditions allow very few nucleotides mismatches to give a positive result. As the technique most commonly involves blotting the test sample onto a membrane and then incubating the membrane in a hybridization solution in the presence of the probe, it is called dot-blot or sap spot hybridization.

Although dot-blot hybridization was first used to detect viroids (Owens \& Diener, 1981) for which no other sensitive and convenient technique for large-scale testing was available, it has been regularly applied to the detection of several viruses, since the first works of Maule et al. (1983) and Baulcombe et al. (1984). Dot-blot hybridization has some potential advantages over serology. ELISA tests are based on the detection of epitopes of the coat protein which corresponds to the expression of only a small portion of the genetic information of the viral genome. On the contrary, probes for hybridization analysis can be chosen on the whole genome. Therefore, it is possible to select and prepare probes which detect specific parts of the virus genome. The probes can thus be chosen for specific purposes, for example to study the genomic isolates from different (geographical) origins. From a more practical point of view, dot-blot hybridization allows the development of very specific strain-dependent detection, or, on the contrary, more polyvalent detection by use of small-sized probes or less stringent hybridization conditions. This possibility for development of either strain-specific, virusspecific, or even group-specific detection techniques is further enhanced by the more recent technique of amplification of specific nucleic acid sequences by PCR.

For detection of RNA viruses, which are by far the most frequent in plants, two types of nucleic acid probes can be used: cDNA or cRNA. We used only cDNA probes. Complementary DNA probes can be obtained from purified virus nucleic acid or purified ds-RNA from infected plants, or by reverse transcription and polymerase chain reaction (RT-PCR) from total RNA preparations from infected plants. In order to obtain a sufficient supply of identical probes, they are generally produced from characterized specific ds-cDNA cloned in bacterial plasmids.

The use of radioactive labelling of the probe has been an important limiting factor for the use of dot-blot hybridization, in many situations. The recent development of several methods of non-radioactive labelling makes possible many more applications, and allows its use outside research laboratories, for example for routine testing. We used exclusively non-radioactive labelling, and, more precisely, the Dig-labelling system developed by Boehringer. Detection of the hybrids, based on the use of alcaline phosphatase-conjugated anti-digoxigenin antibody, is achieved either by the observation of a coloured precipitate or by impression of a sensitive film support by chemoluminescence.

Some examples for different viruses and host plants, using different approaches for the production of probes, are presented.

\section{Materials and methods}

\section{Virus isolates and plant materials}

An isolate of beet necrotic yellow vein furovirus (BNYVV) was cloned by mechanical (C) $1995 \mathrm{OEPP} / \mathrm{EPPO}$, Bulletin OEPP/EPPO Bulletin 25, 301-313 
inoculation to Chenopodium quinoa of crude sap of a beet leaf showing necrotic vein symptoms, from a field in Doel-Kieldrecht (BE) (Kummert, 1993a). The virus isolate originating from a single local lesion was multiplied in this same plant.

For barley yellow mosaic bymovirus (BaYMV), and barley mild mosaic bymovirus (BaMMV), fresh leaves were obtained from naturally infected barley plants with mosaic symptoms in different fields from the Hesbaye region (BE). Several virus isolates were multiplied by mechanical transmission to plants of the sensitive $\mathrm{cv}$. Travelling, grown in controlled conditions $\left(12 \mathrm{~h}\right.$ artificial light, $15^{\circ} \mathrm{C}$ day, $10^{\circ} \mathrm{C}$ night) (Kummert, 1993b).

The p863 isolate of apple chlorotic leafspot closterovirus (ACLSV) from Prunus domestica received from Dr Candresse (INRA-Bordeaux, FR) and an isolate of apple stem grooving capillovirus (ASGV) received from Dr Jongedijk (NAKB - Den Haag, NL) were multiplied by mechanical transmission to C. quinoa.

\section{Virus purification}

BNYVV was purified from C. quinoa leaves harvested at 14 days after inoculation, as described by Putz \& Kuszala (1978). BaYMV and BaMMV were purified from frozen, systemically infected barley leaves, by the technique of Huth et al. (1984) with minor modifications (Kummert, 1993b). ACLSV and ASGV were purified from frozen, systemically infected leaves of C. quinoa, as described by Dunez et al. (1973).

\section{RNA extraction from purified virus suspensions}

Purified virus suspensions, adjusted to $1 \%$ bentonite, $1 \%$ SDS and $0.2 \%$ sodium iodo-acetate were mixed with 1 volume of phenol and $1 / 3 \mathrm{vol}$ of chloroform-iso amylalcohol (24:1). After centrifugation, the aqueous phase was adjusted to $0.2 \mathrm{M} \mathrm{NaAc}(\mathrm{pH} 5.2)$ and precipitated twice with ethanol ( 2 volumes). The final pellets, resuspended in distilled water, were divided into aliquots and stored at $-70^{\circ} \mathrm{C}$. All the solutions were made with distilled water treated with diethylpyrocarbonate (DEPC, $0.2 \%$ ).

\section{Extraction of total nucleic acids or total RNA from plant tissue}

Leaves were frozen at $-70^{\circ} \mathrm{C}$ and then ground to a powder in the presence of polyvinyl polypyrrolidone. For the extraction of total nucleic acids, the powder was homogenized in STE buffer containing $0.5 \%$ SDS and $0.05 \% \beta$-mercaptoethanol ( 1 volume), phenol $(0.5$ volume) and chloroform-isoamylalcohol (24:1-0.5 volume). The aqueous phase was reextracted with phenol and the nucleic acids precipitated twice by ethanol. Final pellets were solubilized in sterile distilled water. Total RNA was extracted by the method of Chirgwin et al. (1979).

\section{Synthesis of cDNA}

The four genomic RNAs of BNYVV possessing a $3^{\prime}$ polyadenylate extremity were purified further by chromatography on oligo(dT) cellulose (Aviv \& Leder, 1972) as described by Sambrook et al. (1989). Four $\mu \mathrm{g}$ of the purified BNYVV-RNA preparation thus obtained were transcribed into double-stranded cDNA by using the cDNA synthesis system plus (Amersham), with oligo(d $\left.\mathrm{dT}_{12-18}\right)$ primers.

For PCR amplification of specific viral nucleotide sequences, single-stranded cDNA was synthesized from $5 \mu \mathrm{g}$ of total RNA preparations from virus-infected plants using the cDNA first strand synthesis kit (Amersham) with random primers.

C 1995 OEPP/EPPO, Bulletin OEPP/EPPO Bulletin 25, 301-313 


\section{PCR amplification of viral nucleotide sequences}

PCR experiments were performed as described previously (Colinet \& Kummert, 1993). Thermal cycling scheme was: template denaturation at $94^{\circ} \mathrm{C}$ for $30 \mathrm{~s}$, primer annealing at $50^{\circ} \mathrm{C}$ for $1 \mathrm{~min}$, and DNA synthesis at $72^{\circ} \mathrm{C}$ for $2 \mathrm{~min}$. A final 15 -min elongation step at $72^{\circ} \mathrm{C}$ was performed at the end of the 37 cycles. Depending on the primers, the annealing temperature could have been lowered to $40^{\circ} \mathrm{C}$ for the five or ten first cycles, and a secondary amplification conducted for 30 cycles, at a primer-annealing temperature of $50^{\circ} \mathrm{C}$, from $1 \%$ of the product purified from the first amplification.

Amplification products were analysed by electrophoresis of $10 \mu \mathrm{l}$ from each reaction mixture in a $1 \%$ agarose gel in Tris-acetate-EDTA buffer (Sambrook et al., 1989). Bands were visualized by ethidium bromide staining.

\section{Cloning of selected cDNA}

\section{Double-stranded cDNA from purified viral $R N A$}

Synthetic EcoRI linkers are ligated to the termini of double-stranded methylated cDNA (Sambrook et al., 1989). After cleavage with the appropriate restriction enzyme, the cDNA molecules can be inserted into plasmid cleaved with a compatible enzyme.

\section{PCR amplified products}

In order to facilitate the subsequent cloning of the PCR products, sequences containing Eco RI or BamHI restriction sites were added at the $5^{\prime}$ end of all the primers used. Amplification products were extracted twice with phenol-chloroform, precipitated by addition of 0.1 volume of $3 \mathrm{M}$ sodium acetate, $\mathrm{pH} 5.8$, and two volumes of ethanol. The pellets were resuspended in $50 \mu \mathrm{l}$ of water and digested with BamHI and EcoRI. After electrophoresis in 1\% agarose gel, the bands of the expected lengths were excised and eluted with the QIAEX Gel. Extraction Kit from QIAGEN

\section{Cloning in bacterial plasmids}

The DNA fragments were inserted into the EcoRI or BamHI sites of clived and dephosphorylated plasmids (pUC18 or pBluescript) or directionally inserted into a BamHI-EcoRI site of the Bluescript plasmid. After cloning in Escherichia coli, strain JM 105, recombinant plasmids were monitored for appropriate size inserts by cleavage with EcoRI (pUC18) or PvuII (pBluescript).

\section{Labelling of the probes and detection of the hybrids}

Digoxigenin labelling of probes was performed by incorporation of DIG-11-dUTP, via random primed $\mathrm{cDNA}$ synthesis, with the DIG-DNA labelling kit from Boehringer according to the manufacturer's instructions.

Detection of the hybrids resulted from the activity of alkaline phosphatase conjugated to an anti-digoxigenin antibody.

The signal was detected either with colorimetric or chemoluminescent substrates by using the DIG nucleic-acid detection kit or the DIG luminescent detection kit (Boehringer).

\section{Dot-blot hybridization}

\section{Denaturation of the samples}

Crude plant sap ( $1 \mu \mathrm{g}$ in $3 \mathrm{ml}$ of TE buffer $+0.5 \%$ SDS) and purified virus suspensions were deposited on the membrane without any previous treatment. 
Purified virus RNA was denatured by incubation for $1 \mathrm{~h}$ in the presence of glyoxal (Sambrook et al., 1989).

Total nucleic acid or total RNA extracts from plants, as inserts DNA, were denatured by heating for 3 min at $95^{\circ} \mathrm{C}$, and then rapidly cooled on ice.

\section{Membrane preparation and deposit of the samples}

Nitrocellulose membranes (Hybond-C, Amersham) were soaked in boiling water for $5 \mathrm{~min}$ and then equilibrated in $20 \mathrm{X}$ SSC. Nylon membranes (Hybond-N, Amersham) do not require any pretreatment. Squaring $(1 \times 1 \mathrm{~cm})$ was drawn with pencil on the membrane, which was then placed on a filter paper. After preparation of successive dilutions of the samples with DEPC treated distilled water, on a sheet of Parafilm, samples (1 or $2 \mu 1$ ) were spotted on the membranes. Nucleic acids were fixed on the membrane by heating in a oven for $2 \mathrm{~h}$ at $80^{\circ} \mathrm{C}$ (nitrocellulose membrane) or by exposure to UV $(254 \mathrm{~nm})$ for 5 min on a transilluminator, after drying for $5 \mathrm{~min}$ at $80^{\circ} \mathrm{C}$ (nylon membrane).

\section{Prehybridization and hybridization}

Membranes were placed in sealed plastic bags containing $20 \mathrm{ml}$ of prehybridization solution and immerged for $3-4 \mathrm{~h}$ at $65^{\circ} \mathrm{C}$ under agitation.

The prehybridization solution was removed, and replaced by $5 \mathrm{ml}$ of hybridization solution containing $60 \mathrm{ng}$ of labelled cDNA probe, denatured by heating for $3 \mathrm{~min}$ at $95^{\circ} \mathrm{C}$ and then cooled on ice water. Hybridization was for $15-20 \mathrm{~h}$ at $65^{\circ} \mathrm{C}$ under agitation.

Prehybridization solution consisted of: $3 \times$ SSC, $0.1 \%$ SDS, $5 \times$ Denhardt $(0.1 \%$ Ficoll, $0.1 \%$ polyvinylpyrrolidone, $0.1 \%$ bovine albumine in water) plus $0.1 \mathrm{mg} \mathrm{ml}^{-1}$ of denatured DNA from herring sperm. Hybridization solution was the same, but $10 \%$ sodium dextran sulphate was added.

The membranes were washed successively at $65^{\circ} \mathrm{C}$ for $3 \times 20 \mathrm{~min}$ in $2 \times \mathrm{SSC}+0.1 \% \mathrm{SDS}$ and for $2 \times 30 \mathrm{~min}$ in $0.2 \times \mathrm{SSC}+0.1 \% \mathrm{SDS}$.

Revelation of the hybrids was conducted according to the protocols of the manufacturer (Boehringer).

\section{Results and discussion}

The aim of our work was to develop a technique of detection based on nucleic acid hybridization, able to detect viral RNAs in plants, with an adequate sensitivity and selectivity, by using non-radioactive cDNA probes.

Hybridizations were conducted generally with $60 \mathrm{ng}$ of probes labelled with digoxigenin and incubated in $5 \mathrm{ml}$ of hybridization solution (for a nylon membrane of $10 \times 10 \mathrm{~cm}$ ).

The first experiments were performed according to the protocols of hybridization and revelation given by the manufacturer (Boehringer). This proved to be inefficient, being unable to detect $5 \mathrm{pg}$ to $500 \mathrm{ng}$ of purified BNYVV-RNA, although $5 \mathrm{pg}$ of homologous DNA (insert DNA used for the synthesis of the probe) were easily detected in the same conditions.

Different methods of denaturation of the RNA, as well as its mode of fixation on the membrane and the use of different types of membrane, did not improve results.

We have thus modified the experimental protocol by changing the prehybridization and hybridization solutions of Boehringer for the classical solution $(3 \times \mathrm{SSC}+$ $5 \times$ Denhardt $+0.1 \%$ SDS $)$ containing denatured DNA as blocking agent $\left(100 \mu \mathrm{g} \mathrm{ml}^{-1}\right)$, as we used before for radioactive probes. In this case, the detection limits observed with probe S19 (a 1400-bp DNA complementary to sequences of BNYVV-RNA3) either labelled with (C) 1995 OEPP/EPPO, Bulletin OEPP/EPPO Bulletin 25, 301-313 
Table 1. Detection limits of BNYVV, its RNA or its homologous cDNA for 8 digoxigenin-labelled probes Limites de détection du BNYVV, de son ARN ou d'ADNc homologue de la sonde, pour 8 sondes marquées à la digoxigénine

\begin{tabular}{lcccc}
\hline & & \multicolumn{3}{c}{ Detection limit (pg) } \\
\cline { 3 - 5 } DNA probe & Hybridization specificity & BNYVV & BNYVV-RNA & Insert DNA \\
\hline S29 & RNA1 & 220 & 3.6 & 0.4 \\
S39 & RNA1 & 220 & 10.8 & 0.4 \\
S49 & RNA2 & 75 & 1.2 & 0.4 \\
S51 & RNA2 & 220 & 3.6 & 1.2 \\
S6 & RNA3 & 220 & 3.6 & 3.6 \\
S19 & RNA3 & 75 & 0.4 & 0.4 \\
S45 & RNA4 & 25 & 0.4 & 3.4 \\
S54 & RNA4 & 220 & 10.8 & 3.6 \\
\hline
\end{tabular}

Nylon membranes $(10 \mathrm{~cm} \times 10 \mathrm{~cm})$; hybridization for $16 \mathrm{~h}$ in the presence of sodium dextran sulphate $(10 \%)$ with $60 \mathrm{ng}$ of labelled probes; colorimetric detection.

digoxigenin (revealed by coloured precipitate) or with ${ }^{32} \mathrm{P}$ (revealed by autoradiography for 16 h) were of about $100 \mathrm{pg}$ of total BNYVV-RNA or $2.4 \mathrm{ng}$ of purified viral suspension. The radioactive labelling proved more efficient only if the autoradiography was conducted for several days, allowing the visualization of the spot corresponding to the deposit of $10 \mathrm{pg}$ of BNYVV-RNA.

Another modification which proved favourable to increase the detection limit was the addition of $10 \%$ dextran sulphate to the hybridization solution. The polymer apparently excludes the probes from the volume it occupes, increasing the apparent concentration of the probe, or favours the formation of a network of probes.

In the conditions of the test thus described, with DIG-labelling, denatured DNA as blocking agent, and in the presence of dextran sulphate in the hybridization medium, the limits of detection we obtained were comparable to those reported by different authors for dot-blot detection of RNA plant viruses with radioactive probes.

Table 1 presents the synthesis of the results obtained for eight different probes. It can be seen that the higher sensitivity is found for probes corresponding to RNA3 and RNA4, and correlates to the respective amounts of the four genomic RNAs in a total RNA preparation from purified virus suspension.

Considering the good results obtained for detection of purified virus or viral RNA, we tried to use the same detection scheme for identification of BNYVV infection in C. quinoa. Using crude sap, coloured spots were observed for extracts of healthy plants diluted $1 / 3$ to $1 / 9$ (and sometimes $1 / 27$ ), whereas positive reactions were obtained for extracts of virus-infected plants diluted $1 / 243$. On the other hand, if phenol-extracted total nucleic acids from plants were used, they allowed specific and sensitive detection of BNYVV infection (up to dilution 1/143), without any interference of healthy plant components.

Fig. 1 shows the application of the same technique, using total nucleic acid preparations for the detection of BNYVV infection of beet roots. In this case, results obtained were perfectly correlated to those observed when aliquots from the same samples were analysed by ELISA.

The same approach has been used for the detection of ACLSV and ASGV. Fig. 2 presents the genomic organization of ACLSV-RNA, and localizes the different probes used. S1, S2 and $\mathrm{S} 3$ were synthesized from cloned cDNA obtained from the pCLS55 M plasmid received from T. Candresse whereas PCR1, PCR2 and PCR3 were obtained by cloning PCR amplification

(C) 1995 OEPP/EPPO, Bulletin OEPP/EPPO Bulletin 25, 301-313 


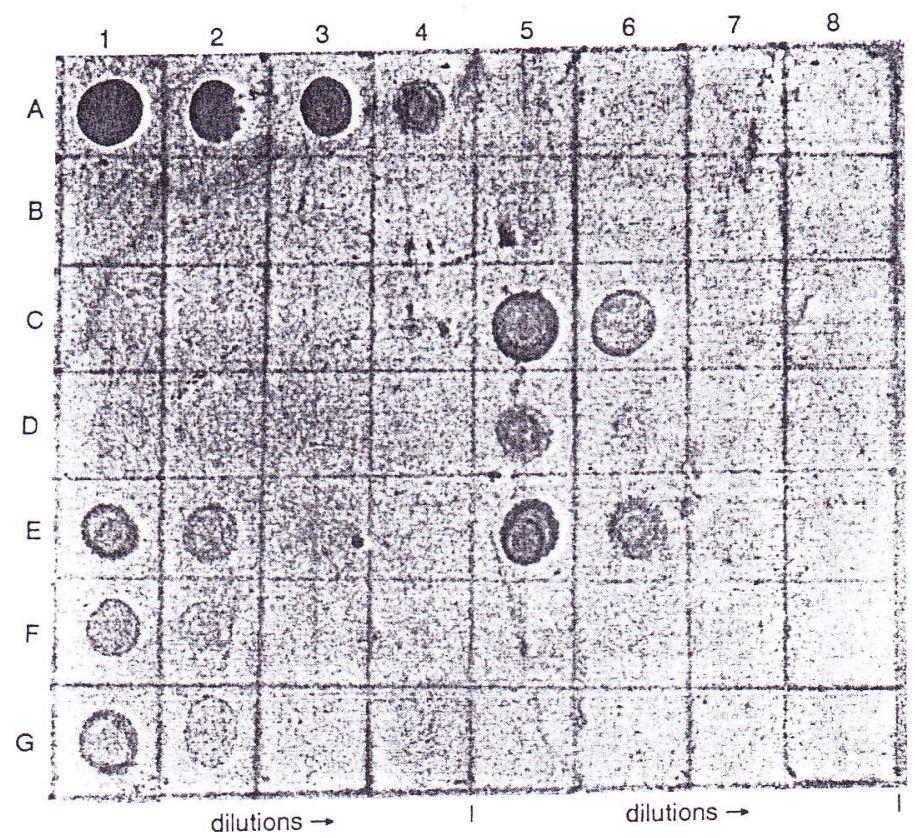

Fia. 1. Dot-blot hybridization for the detection of BNYVV infection in beet roots. Nylon membrane Fig. 1. Dot-blot hybridization for the detection of BNY total nucleic acid extracts is shown; the first $(10 \times 10 \mathrm{~cm})$ spotted with four successive 3 -fold dilutions of total nucleic acid extracts is shown, the frs spot corresponds to total nucleic acid extract from $1 \mathrm{mg}$ of plant tissue (fresh weight), A:leaves of infected ( $1-4)$ or healthy (5-8) Chenopodium quinoa (control); B (1-4): roots of healthy beet; B (5-8), C $(1-\mathrm{G}$ 4), C (5-8), D (1-4), D (5-8), E (1-4), E (5-8), F (1-4), F (5-8), Hybridization with $60 \mathrm{ng}$ of probe $\mathrm{S} 19$ in the (5-8): hybridization buffer without nucleic acid ext

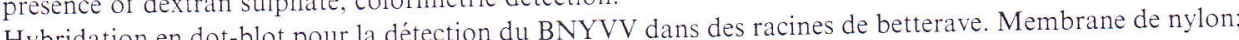
dépôts de 4 dilutions successives d'acides nucléiques totaux de feuilles de C. quinoa virosées (A 1-4) ou saines (A 5-8), de racines de betterave saines (B 1-4) ou de racines de betterave de différentes origines, soumises au test (B 5-8 à G 1-4); sonde S19; détection colorimétrique.

products. PCR1 and PCR2 were obtained with primers chosen by analysis of nucleotide sequences of ACLSV p863 (German et al. 1990). PCR3 resulted from RT-PCR amplification with primers corresponding to a conserved region in the genomic RNA of ACLSV p 863 and ASGV (Yoshikawa et al., 1992) found in the $3^{\prime}$ terminal part of the putative gene of the viral RNA polymerase.

Fig. 3 illustrates the results obtained for the detection of ACLSV strain p 863 in extracts of $C$. quinoa or as purified virus suspension, by using the DIG-labelled probe S1 (cDNA insert of 2 . kbp) in dot-blot hybridization assay on nylon membrane and detection of the hybrids by coloured precipitates.

The same probe PCR1 (1 kbp) was used in dot-blot hybridization for the detection of ACLSV p 863 in crude extracts of healthy or virus-infected $C$. quinoa and revealed either by colorimetric detection (coloured precipitate in the presence of BCIP and NBT) or chemoluminescence in the presence of Lumigen PPD (4-metoxy-4-(3-phosphatephenyl)spiro-(1,2-dioxetane-3,2-adamantane)). In this case, better results were observed for the chemoluminescent detection.

Fig. 4 presents an example of the results obtained for ASGV with probe PCR3 obtained by cloning the RT-PCR amplification product from a total RNA preparation from ASGV(C) 1995 OEPP/EPPO, Bulletin OEPP/EPPO Bulletin 25, 301-313 


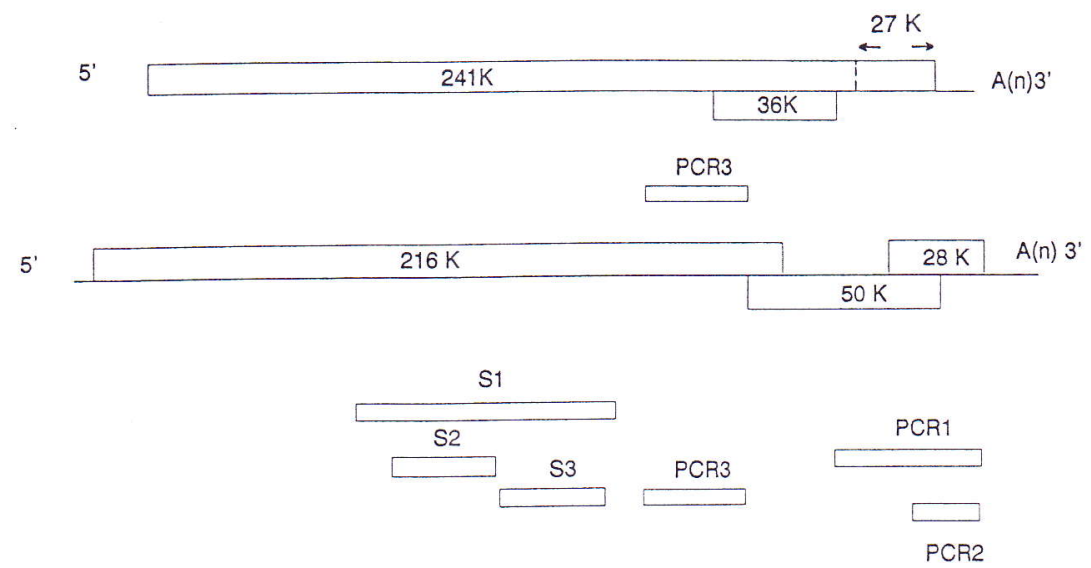

Fig. 2. Schematic representation of the genomic organization of ACLSV (from German et al., 1990) and ASGV (from Yoshikawa et al., 1992), and localization of the sequences corresponding to the different probes used for dot-blot hybridization.

Représentation schématique de l'organisation du génome de l'ACLSV et de l'ASGV, et localisation des séquences correspondant aux sondes utilisées en dot-blot.

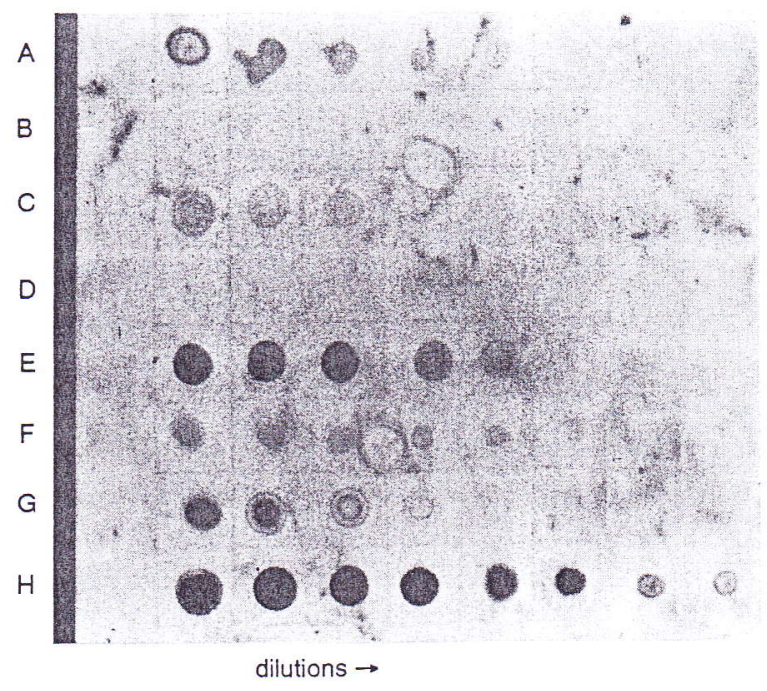

Fig. 3. Use of probe S1 (ACLSV-cDNA $2.1 \mathrm{kbp}$ ) for the detection of virus infection in dot-blot hybridization. Nylon membrane spotted with successive 3 -fold dilutions of $2-\mu 1$ samples is shown: crude sap of infected (A) or healthy (B) Chenopodium quinoa leaves (first spot corresponding to $3 \mu \mathrm{g}$ of leaf tissue; fresh weight), total nucleic acids from infected (C) or healthy (D) leaves (first spot corresponding to $2 \mu \mathrm{g}$ of nucleic acids), total RNA from infected plants ( $E, F=$ two different preparations; first spot corresponding respectively to 2400 or $420 \mathrm{ng}$ ), purified virus suspensions ( $\mathrm{G}, \mathrm{H}=$ two different preparations of ACLSV p863; first spot corresponding to 500 or $920 \mathrm{ng}$ ). DIG DNA labelling; colorimetric detection.

Utilisation de la sonde S1 (ADNc-ACLSV; $2,1 \mathrm{kpb}$ ) pour la détection de l'infection virale par hybridation en dot-blot. Membrane de nylon; dépôts de dilutions successives de jus brut de C. quinoa infectés (A) ou sains (B), d'acides nucléiques totaux de feuilles infectées (C) ou saines (D), d'ARN totaux de plantes infectées (E, F) ou de suspensions virales purifiées $(G, H)$. Détection colorimétrique.

(C) $1995 \mathrm{OEPP} / \mathrm{EPPO}$, Bulletin OEPP/EPPO Bulletin 25,301-313 


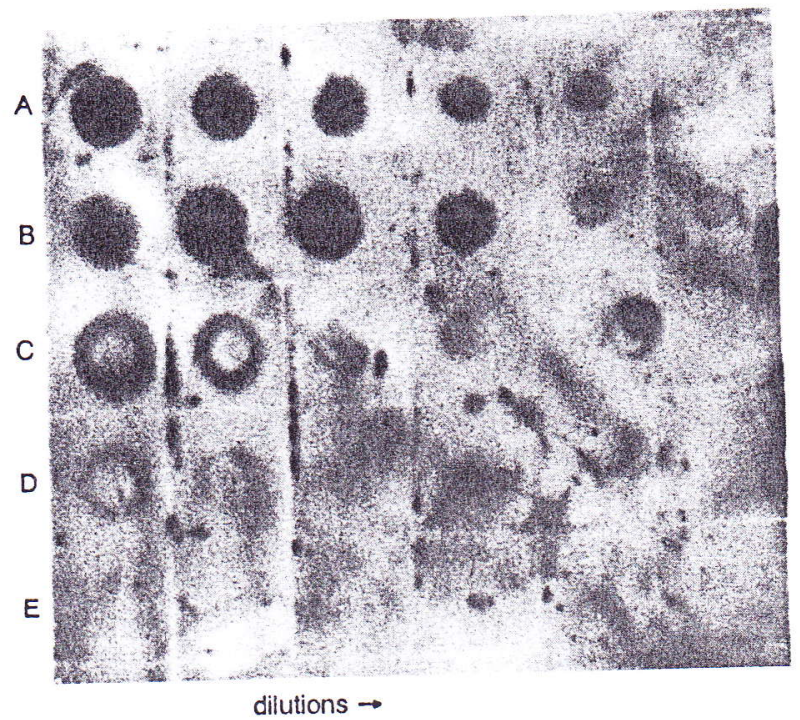

Fig. 4. Use of probe PCR3 (ASGV-cDNA 640 bp) for the detection of ASGV in dot-blot hybridization. Nylon membrane spotted with successive 3 -fold dilutions of 2 - $\mu$ l samples (concentrations of the first deposit are given) is shown. DIG labelling and chemoluminescent detection. A: suspension of purified ASGV (400 ng); B: purified ASGV-RNA (10 $\mu \mathrm{g})$; C: crude sap from ASGV-infected Chenopodium quinoa leaves (1 g per $3 \mathrm{ml}$ ) D. crude sap from healthy C. quinoa leaves ( $1 \mathrm{~g}$ per $3 \mathrm{ml})$; E: crude sap from ACLSV-infected C. quinoa leaves (isolate $\mathrm{p} 863 ; 1 \mathrm{~g}$ per $3 \mathrm{ml}$ ).

Utilisation de la sonde PCR3 (ADNc-ASGV, $640 \mathrm{pb}$ ) pour la détection de l'ASGV par hybridation moléculaire en dot-blot. Membrane de nylon; dépôts de dilutions successives d'une suspension virale purifiée (A), d'ARN viral purifié (B), de jus brut de feuilles de C. quinoa saines (D) ou infectées par l'ASGV (C) ou l'ACLSV (E).

infected leaves of $C$. quinoa. Line $C$ shows inhibition of detection by components of crude plant sap. This kind of inhibition is frequently observed for spotting of undiluted or poorly diluted crude sap when using the chemoluminescent detection, but this does not lead to misinterpretation of the results, as can be the case with the colorimetric detection.

Table 2 summarizes the results observed for the different probes developed for ACLSV and ASGV. Probes S1, S2, S3, PCR1 and PCR2, specifically developed from sequences of ACLSV

isolate p863, recognized only plants infected by ACLSV p863. Probe PCR3-ASGV, obtained from cloned products amplified from transcripts of a total RNA preparation from ASGVinfected $C$. quinoa by using primers corresponding to conserved region in ASGV-RNA and ACLSV-RNA, did not recognize ACLSV. The response observed for some later preparations of purified ASGV or total RNA from ASGV-infected leaves, with the large ACLSV probe S1 $(2.1 \mathrm{kbp})$ seems to indicate a contamination of our ASGV isolate by ACLSV in the glasshouse.

The same procedures have been used to develop dot-blot hybridization tests for the detection and the characterization of BaYMV and BaMMV infection in barley. The different RT-PCR amplification products presented by Colinet et al. (1995) have been prepared for insertion in the Bluescript plasmid and cloning in E. coli. As some of the amplified products possessed either an Eco RI, a BamHI, or both restriction sites, the cloning strategies have been adapted accordingly and the sizes of the probes thus obtained may be different from that of the corresponding amplification products (Table 2, Colinet et al., 1995).

Preliminary tests using purified virus preparations and crude sap of healthy leaves have shown that the detection limit of the virus is greatly reduced in the presence of crude sap of (C) 1995 OEPP/EPPO, Bulletin OEPP/EPPO Bulletin 25, 301-313 
Table 2. Detection limits observed for different probes developed from sequences of ACLSV p863 (S1, S2, S3, PCR1, PCR2) or of ASGV (PCR3)

Limites de détection observées pour différentes sondes développées à partir de séquences de l'ACLSV p863 (S1, S2, S3, PCR1, PCR2) ou de l'ASGV (PCR3)

\begin{tabular}{|c|c|c|c|c|c|c|}
\hline & \multicolumn{6}{|c|}{ Detection limit for probe } \\
\hline & $\mathrm{S} 1$ & $\mathrm{~S} 2$ & S3 & PCR 1 & PCR2 & PCR3 \\
\hline \multicolumn{7}{|l|}{ Crude sap (C. quinoa) } \\
\hline Healthy & - & - & - & - & - & - \\
\hline ACLSV-infected $(\mu \mathrm{g})$ & 8 & 37 & 37 & 8 & - & - \\
\hline ASGV-infected $(\mu \mathrm{g})$ & - & - & - & - & - & 25 \\
\hline \multicolumn{7}{|l|}{$\begin{array}{l}\text { Total nucleic acids } \\
\text { (C. quinoa) }\end{array}$} \\
\hline Healthy & - & - & - & - & - & - \\
\hline ACLSV-infected (ng) & 15 & 1 & 31 & 8 & 25 & - \\
\hline ASGV-infected (ng) & NT & NT & NT & - & - & 452 \\
\hline \multicolumn{7}{|l|}{ Total RNAs (C. quinoa) } \\
\hline ACLSV-infected (ng) & 1 & 13 & 13 & NT & NT & - \\
\hline ASGV-infected (ng) & $(56)$ & - & - & - & - & 18 \\
\hline \multicolumn{7}{|l|}{ Purified virus } \\
\hline ACLSV (ng) & 0.2 & 0.4 & 0.4 & 0.4 & 0.4 & - \\
\hline ASGV (ng) & $(700)$ & - & - & NT & NT & 6 \\
\hline \multicolumn{7}{|l|}{ Purified virus RNA } \\
\hline ACLSV (ng) & 0.6 & 1.7 & 1.7 & NT & NT & NT \\
\hline ASGV (ng) & - & - & - & - & NT & 13 \\
\hline
\end{tabular}

Nylon membranes $(10 \mathrm{~cm} \times 10 \mathrm{~cm})$; hybridization for $16 \mathrm{~h}$ in the presence of sodium dextran sulphate $(10 \%)$ with $60 \mathrm{ng}$ of digoxigenin labelled probes; colorimetric or chemoluminescent detection.

barley plants diluted 1/3. For example, $230 \mathrm{pg}$ of purified BaYMV isolate from cv. Express is detected by probe MYP1-MYP2 or Y1-Pot4 (developed from total RNA preparations from barley plants of the cv. Express in Huccorgne), whereas only $21.5 \mathrm{ng}$ of the same preparation is detected in the presence of healthy sap.

Eight different probes, labelled with digoxigenin, have been hybridized to different preparations of crude sap from barley plants from the fields, or from plants of sensitive cultivars grown in controlled conditions, and mechanically inoculated with characterized isolates.

BaMMV specific probes, developed from PCR amplified fragments with both primer sets M1-Pot4 and MYP1-MYP2, detected BaMMV strains in crude sap of all the virus-infected samples tested, except those from cv. Express in Huccorgne. The 400-bp probe (M1-Pot4; E/B), which corresponds to the C-terminal part of the polymerase, hybridized with the cDNA fragments of clone Y1-Pot4 which are specific for BaYMV. These hybridizations, which are only observed at the higher concentrations used, could be explained by the important conservation of nucleotide sequences observed in some parts of the RNA polymerase gene among bymoviruses and potyviruses.

The four probes which are specific for BaYMV all recognized purified virus suspensions from infected barley plants from the fields, although with slightly different detection limits. Furthermore, the cross reactivity observed between the two probes Y1-Pot4 developed from barley plants of cv. Arton in Gembloux and cv. Express in Huccorgne, as between these probes

(C) 1995 OEPP/EPPO, Bulletin OEPP/EPPO Bulletin 25, 301-313 
and $\mathrm{cDNA}$ inserts of the heterologous clones, confirmed the tight relationship existing between these different BaYMV isolates, among which some can overcome the resistance of barley cv. Express in one field located in Huccorgne (Kummert, 1993b).

The fact that no hybridization was generally observed for BaYMV specific probes towards crude sap from barley plants from the fields, with the exception of those from symptom-bearing plants of cr. Express, could be explained by the fact that the tests were done in May, when the concentration of BaMMV remains high, whereas that of BaYMV decreases in plants with mixed infection.

\section{Conclusions}

New possibilities for non-radioactive labelling of nucleic acid probes obviously increase the range of potential use of dot-blot hybridization for the detection of virus infection in plants. However, the indirect techniques generally used for the revelation of the hybrids generate high background when using crude sap. As compared with the colorimetric detection which is based

on the direct observation of a coloured precipitate on the membrane, the chemoluminescent detection system lowers the background generated by plant component, but these may inhibit the signal generated by the labelled hybrid complex. For these reasons, when crude sap is directly spotted on the membrane, the methods of preparation of the samples have to be adapted to the virus/host plant combination concerned, including the composition of buffer used for grinding, the presence and the type of detergent or adjuvant, and any treatment by heat or with proteases.

When specific antibodies are available, the sensitivity levels of both the DAS-ELISA and the dot-blot hybridization tests using non-radioactive labelling are comparable, but the latter allows the choice of a target on the whole virus genome. Therefore, it is possible to select specific parts of the virus genome, allowing the design of more polyvalent tests or more specific tests to control the presence of satellite RNA, subgenomic RNA or the gene controlling the pathogenicity or the virulence of the virus strain, for example in epidemiological surveys.

The PCR technology, coupled with the cloning of specific amplified products, allows the construction of specific probes when the virus purification is difficult, preventing the production of antibodies or even probes by the classical methods.

\section{Acknowledgements}

This work was financially supported by the IRSIA, Brussels, and by the EU (STD3).

Détection de virus de plantes par hybridation moléculaire à l'aide de sondes à marquage non radioactif

Dans le contexte de la législation phytosanitaire qui régit le commerce des plantes, des techniques fiables, rapides et sensibles de détection des virus doivent être mises au point. De tels objectifs sont rencontrés par l'hybridation moléculaire et la PCR. Des séquences d'acides nucléiques spécifiques d'un virus à ARN peuvent être reconnues directement par hybridation en présence d'une sonde d'ADN complémentaire $(A D N c)$ marquée, synthétisée à partir d'ARN viral purifié, d'ARN bicaténaire extrait de plantes infectées, ou encore à partir d'une préparation d'ARN total de plante infectée, par RT-PCR. Le clonage d'ADNc caractérisés et sélectionnés, à l'aide de plasmides recombinants, permet la disponibilité continue de sondes toujours identiques et homogènes. Les techniques de marquage non radioactif, qui permettent actuellement d'atteindre des objectifs de sensibilité et de spécificité comparables à ceux de la radioactivité, sont utilisées. Les sondes spécifiques sont généralement hybridées à des séquences d'acides nucléiques d'échantillons végétaux immobilisés sur un support solide (hybridation en C) 1995 OEPP/EPPO, Bulletin OEPP/EPPO Bulletin 25, 301-313 
dot-blot). Plusieurs exemples intéressant différents virus et différentes plantes-hôtes et montrant les possibilités et les performances de l'hybridation moléculaire pour le diagnostic de l'infection virale chez les plantes sont présentés.

\section{Детектирование вирусов растений путем молекулярной гибридизацин с применением нерадиоактивньх зондов}

В рамках фитосанитарного законодательства, управляюшего торговлей растениями, возникла необходимость разработки точных, высокочувствительньх методик детектирования вирусов. Эта цель может быть достигнута с помощью молекулярной гибридизации и полимеразной цепной реакции синтеза. Типичные последовательности нуклеиновых оснований в молекуле вирусной РНК могут быть непосредственно узнаны при гибридизации в присутствин меченого комплиментарного зонда ДНК (кДНК), полученного либо из вирусной PHК, двунитевой РНК от зараженных растений, либо из препаратов полноразмерной PHК, выделенной из инфицированных растений, с помощью обратной транскрипцииполимеразной цепной реакции синтеза. После установления свойств и селекции молекулы кДНК с характерной нуктеотидной последовательностью ктонируются в бактерии с помощью рекомбинантных плазмид, создавая таким образом постоянный запас идентичных гомологичных зондов. Используются также методики нерадиоактивной метки, позволяющие достигнуть уровней чувствительности и специфичности, сходных с методами, в которых используется радиоактивная метка. Специфичные зонды обычно образуют гибриды с последовательностями нуктеотидных оснований растительных проб, иммобилизованных на твердой подложке (дот блот гибридизация). Представлены несколько примеров различных вирусов и растений-хозяев и демонстрируются возможности и характеристики применения молекулярной гибридизации для диагностики вирусных инфекций растений.

\section{References}

Aviv, H. \& Leder, P. (1972) Purification of biologically active globin messenger RNA by chromatography on oligothymidylic acid cellulose. Proceedings of the National Academy of Sciences of the United States of America 69, 1408-1412.

Baulcombe, D.C., Flavell, R.B., Boulton, R.E. \& Jellis, G. (1984) The sensitivity and specificity of a rapid nucleic acid hybridization method for the detection of potato virus $\mathrm{X}$ in crude sap samples. Plant Pathology 33, 361-370

Chirgwin J., Przybyla, A., MacDonald, R. \& Rutter, W. (1979) Isolation of biologically active ribonucleic acid from sources enriched in ribonuclease. Biochemistry 18, 5294-5299.

Colinet, D. \& Kummert, J. (1993) Identification of a sweet potato feathery mottle virus isolate from China (SPFMV-CH) by the polymerase chain reaction with degenerate primers. Journal of Virological Methods 45, 149-159.

Colinet, D., Kummert, J., Duterme, O. \& Leporvre, P. (1995) Detection of plant viruses by PCR using group'or virus specific primers (potyviruses, bymoviruses). Bulletin OEPP/EPPO Bulletin 25, 289-299.

Dunez, J., Delbos, R. \& Bertranet, R. (1973) Le rôle de différents facteurs de stabilisation appliqués à la purification du virus du chlorotic leafspot du prunier (CLSV). Annales de Phytopathologie 5, 255-264.

German, S., Candresse, T., Lanneau, M., Huet, J.C., Pernollet, J.C. \& Dunez, J. (1990) Nucleotide sequence and genomic organization of apple chlorotic leaf spot closterovirus. Virology 179, 104-112.

Huth, W., Leseman, D.E. \& Paul, H.L. (1984) Barley yellow mosaic virus: purification, electron microscopy, serology and other properties of two types of the virus. Phytopathologische Zeitschrifi $111,37-54$

Kummert, J. (1993a) Viroses transmises par Polymyxa. Le diagnostic des agents viraux: techniques immunologiques et hybridation moléculaire. II. Diagnostic du virus des nervures jaunes et nécrotiques de la betterave par hybridation moléculaire en dot blot. Parasitica 49, 87-104.

Kummert, J. (1993b) Viroses transmises par Polymyxa. Le diagnostic des agents viraux: techniques immunologiques et hybridation moléculaire. I. Diagnostic et caractérisation des agents de la mosaïque jaune de l'orge par le test sérologique ELISA. Parasitica 49, 67-85.

(C) 1995 OEPP/EPPO, Bulletin OEPP/EPPO Bulletin 25, 301-313 
Maule, A.J., Hull, R. \& Donson, J. (1983) The application of spot hybridization to the detection of DNA and RNA viruses in plant tissues. Journal of Virological Methods 6, 215-224.

OWens, R.A. \& Diener, T.O. (1981) Sensitive and rapid diagnosis of potato spindle tuber viroid disease by nucleic acid hybridization. Science $\mathbf{2 1 3}, \mathbf{6 7 0 - 6 7 2 .}$

Putz, C. \& Kuszala, M. (1978) La rhizomanie de la betterave sucrière en Alsace. Recherche d'une nouvelle méthode de purification du 'beet necrotic yellow vein virus'. Annales de Phytopathologie 10, 247-262.

Sambrook, J., Fritsch, E.F. \& Maniatis, T. (1989) Molecular cloning: A Laboratory Manual, $2^{\text {nd }}$ ed. Cold Spring Harbor Laboratory, Cold Spring Harbor, New York (US).

Yoshikawa, N., Sasaki, E., Kato, M. \& TAkahashi, T. (1992) The nucleotide sequence of apple stem grooving capillovirus genome. Virology $311,98-105$. 